\title{
Social Engineering Model for Character Education in Higher Education
}

\author{
Nurul Zuriah \\ University of Muhammadiyah Malang \\ zuriahnurul@gmail.com
}

\begin{abstract}
The focus of the research is to construct and develop a civic virtue and local wisdom-based character education program model in higher education. The research was conducted in three universities: UMM, UNS, and UPI. A Qualitative and quantitative research approach with development research design was employed. The techniques of data collection adopted were references, observations and questionnaires with Delphi technique. The data were analysable using the mix between descriptive qualitative research and library research, accompanied with heuristic, critical, interpretative. The result in the second year is in the form of a draft of the social engineering construction of a civic virtue and local wisdom values-based education model where it was variously applied in each high education, depending on the policy and nomenclature prevailed in each higher education. But, as synthesis and collaboration, the social engineering draft of the nation character education model is developed into an Input - Process - Output plot. Some models of character education developed in higher education in Indonesia are best practices of the character education resulting from the social engineering and the integrative synergy from all existing components and involve many parties in the implementation
\end{abstract}

Keywords: social engineering, character education, civic virtue

\section{INTRODUCTION}

The education of the nation's character plays a very strategic role in the national development. Therefore, a grand design of character education as part of the efforts in building the nation's character is in a great need. The character education is regulated in the Act of the Republic of IndonesiaNo. 20 year of 2003 on the National Education System. In the article 3, it is stated that "The National Education functions to develop the capability, character, and civilization of the nation for enhancing its intellectual capacity, and is aimed at developing learners' potentials so that they become persons imbued with human valueswho are faithful and pious to one and only God; who possess morals and noble character; who are healthy, knowledgeable, competent, creative, independent; and as citizens, are democratic and responsible." For a nation, character is virtue values clinging in each individual citizen and then manifesting as the national collective personalityand identity. Character functions as a mental and ethical power encouraging a nation to realize its national ideals and to display comparative, competitive, and dynamic superiorities among other nations.In the Grand Design of the Development of the Nation's Character Education in the Ministry of Education of the Republic of Indonesia, it is stated that there are 3 (three) aspects that build noble characters: (a) Religion, Pancasila (Five Basic Principle), 1945 Constitution and Act of National Education System, (b) Theories of Education, Psychology, and Socio-cultural Values, and (c) the best practices and the best real practices. In fact, the three aspects or poles of these noble characters are very bias in nature.

Indonesia people are a plural society in terms of either the culture, religion, or language with noble values as the local wisdom. Some traditional societies still exist at present. They have been maintaining their local wisdoms that are inseparable parts from their lives and that become the basis for solving problems appearing in the societies. The ethnicity values at the local level and cosmopolitan values at the global level which are not well managed may result in some disharmonies that may spoil the oneness and unity of the nation. Based on the descriptions above, there are two things to pay attention. First is the emergence of the phenomenon of the decline of noble character among the university students. Second is that there is no model of character education which is in line with the religion and culture values that may build university students' character. Therefore it is necessary to find out and to formulate character education which may be effectively implemented in higher education environment. Each ethnic group in this diverse Indonesian nation has its own cultures, noble culture values, and its own local knowledge, and local wisdoms. As a result, it is necessary to think, formulate and find a civic virtue and local wisdom-based character education modelfor Indonesian people who are culturally plural. As an effort to realize the aim of the national education and to make the character education as a part of the efforts, the government together with the concerned parties in the society shouldmake various breakthrough programs to continuously socialize character education so that strategic steps may be taken to implement the programs. Certainly, all universities should support these programs. From the observations of the development of character education in higher education, it can be stated that character education in some universities has not been running in a programmed and systematic way. Therefore, it has not given significant impacts on the people at the national level. Various experiences gained by various higher education institutions may be used as 
references for best practices that may be implemented in each higher education.

In the context of the study of the Social Engineering of the Character Education Model in Higher Education in Indonesia, since the last two years, the National Strategic Researches team and the researchers (2016 and 2017) have made some researches and studies, especially those dealing with:1. INPUT covering 4 aspects, namely: (a) Philosophical Foundation, (b) Vision \& Mission of Higher Education, (c) Contents/Values developed, (d) Branding of the Higher Education. 2. PROCES covering 4 aspects, namely: (1) Strategy of the Implementation, (2) Approach to the Implementation, (3) Models or forms of the implementation of the character education that have been made use of by Higher Education; (4) Programs/activities done to implement the character education in Higher Education. 3.OUTPUT covering 4 aspects, namely: (1) Evaluation of the success of the Program, (2) Reward and Punishment, (3) Follow up Plan, and (4) Self-evaluation in each Higher Education.The results of the study would be written in detail in the book report of research results. The basic assumption of the studies and researches is that through character education, university students become young intellects of the national possessing superior personality as stated in the the goal of national education. The implementation of character education in higher education should not only give cognitive knowledge but also affective, conative, and skill knowledge. What should be paid attention in the learning process of character education is that it should be applied in each course so that all teachers, lecturers, and staffs have a sense of caring for this nation.

Social engineering at least should also be lead into the concept and dimension. Social engineering may simply be interpreted as an action to influence social attitudes and actions in a wide scale. The term "social engineering" was born in the Soviet Union in 1920s to to overthrow the power of Tsar. The government of the Soviet Union used newspapers, books, films, architectural materials to change the order and structures of the people's ideology (Handoko, 2013 and Wulandari, 2016).

Moreover, Wulandari (2016) states that social engineering is a way to make planned social changes. The concept of social engineering basically is in the form of a planned social change. A social engineering deals with efforts to realize certain vision, missions and aims. The process to a social change should start from ideas on the three things. The social engineering should be done as quickly as possible, since it deals with efforts to realize the vision, missions, and aims of the character affirmation of the Indonesian people based on Pancasila as the common platform, crystallized into the five main values: religious, nationalist, autonomous, self-help and integrity (RENAMAGI.

Then the results of this research and study are expected to produce findings on a draft of the social engineering of civic virtue and local wisdom-based character education model as an effort to reinforce the development of human beings and the nation's competitiveness in the higher education environment.

\section{METHOD}

Theoretically and methodologically, this present research employed a qualitative approach supported by a quantitative approach. The research design that was used is developmental research. This design is considered very appropriate for research activities that aim to produce a product that is valid, practical, and effective. Research and Development ( $R \& D)$ method is a research process used to develop and validate educational products, and one of the products that would be developed is a learning program.

Meanwhile, Sukmadinata (2010) also state that research and development is a process or step to develop a new product, or to perfect the existing product to make the product able to be accounted. It is in line with opinion raised by Sukmadinata (2005) stating that the ten research and development steps proposed by Borg \& Gall (1988) may be modified into threestages covering:(1) preliminary study,(2) development, and (3) testing and reporting.

\section{RESULT}

Social Engineering of the Civic Virtue and Local Wisdom-based Character Education Model was made in 3 (three) stages: 1) developing the concept of the model, 2) developing the product of the model, and 3) trying-out of the model. The description of the chart for the three development stages is presented below:

Design and Procedure in the Concept Development, at this stage, characteristics of the components at each stage in the development, analytic explanations of functions in each component at each stage of product development, and explanations of interrelation among components in the system are presented. In understanding the model design of the learning system, the design should be understood and grouped.According to Gustafson and Branch(2002), the model design of the learning system may be classified into three groups" 1) classroom-oriented, 2) product-oriented, and 3) systemoriented. The product-oriented learning system is based on the assumption that the engineering design of the civic virtue and local wisdom-based character education model for reinforcing human resources and the nation'scompetitiveness is developed in a certain time period.This learning design model applied a very tight need analysis.

The design of this development program has 6 (six) main components in line with a theory developed by Richey and Klein (2007). The six components are focused on elements which are different from the design and development efforts, namely (1) the students and how they learn, (2) the context in which they learn and their performance, (3) the nature of the learning contents and how they are ordered,(4) learning strategies and activities implemented, (5) media and system of 
presentation employed, and (6) the designers themselves and the process they follow. The development design covering the scope is presented in Picture 1 below.

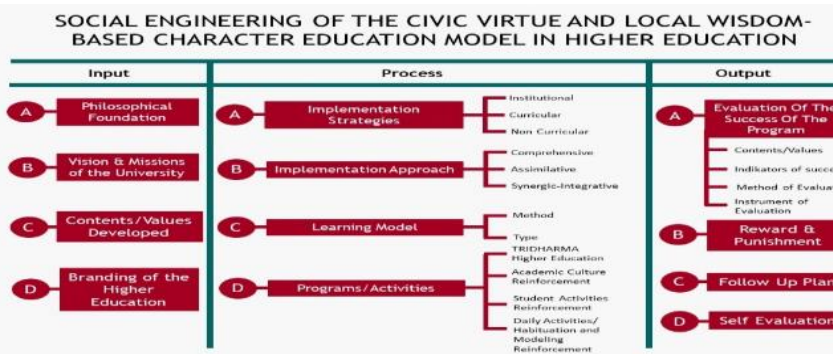

Picture 1. Design of Development of the Engineering of the Civic Virtue- and Local Wisdom-based Character Education Model in Higher Education (zuriah et.all.2017)

\section{Product Tryout}

Product tryout here is intended to result in a valid learning model. The tryout was made through 2 (two) ways, namely action research and quasi experiment. The action research is intended to know whether the procedures used in developing the character education had fulfilled or not, while the experiment made was quasi in nature intended to test the effectiveness and the usefulness of the model.

2. Product and Publication of Civic Virtue and Local

Wisdom-based Character Education Model Developed

As a product from the results of the social engineering of the nation's character education model, some characteristics of the model and its foundation of thought are presented in Picture 2 as follows.

Foundation of Thoughts Ofsocial Engineering Of Civic Virtue and Local Wisdom-Based Character Education Model

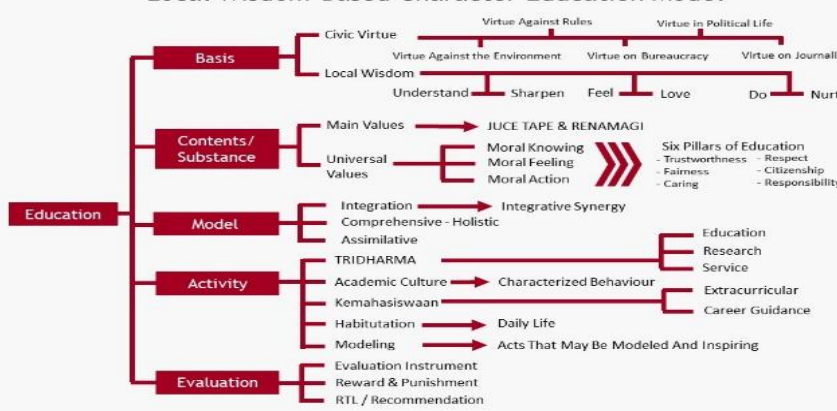

Picture 2. Foundation of Thought of the Social Engineering of the Civic Virtue and Local Wisdom-based Character Education Model in Higher Education

The scope of the Social Engineering of the Civic Virtue and Local Wisdom-based Character Education
Model in Higher Education in Higher Education include the dimensions of (1) Behavior, (2) Value, (3) Personality, (4) Emotion, (5) Reasoning, (6) Self-identity and (7) Basic Character, all of which are united in four dimensions, namely (1) kinesthetic (olah raga), (2) literacy (olahpikir), (3) aesthetic (olah rasa) and (4) ethic and spiritual (olahhati)). See Picture3.

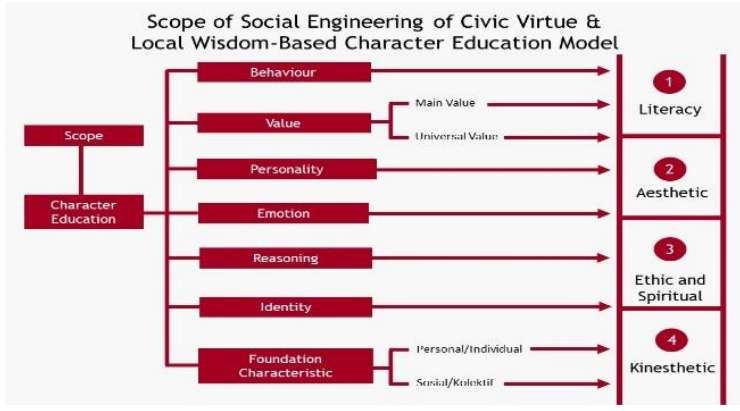

Picture 3. Scope of the Social Engineering of the Civic Virtue and Local Wisdom-based Character Education Model in Higher Education (zuriah, et.all. 2017)

If it is described comprehensively, the scope of the human character developed in the Social Engineering of the Civic Virtue and Local Wisdombased Character Education Model as an effort to reinforce human resources and the nation's competitiveness is presented in Picture 4.

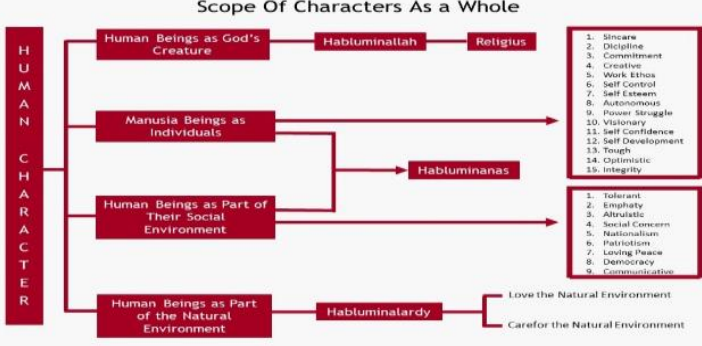

Picture 4. Scope of a Complete Character Education

As a product of the social engineering of the Character Education Model for Indonesian Noble Character Netizen Project, the result of its development is realized in students work in the form of group tasks in making a netizen project of which the development is based on the concept of the netizen project. This project may be seen and accessed directly by the students and all concerned parties, including parents and lecturers in the Internet through You Tube, and a Webb blog. PRONET KARAKTER LUHUR BANGSA INDONESIA) would be created. Moreover, in the future it will also developed through social media such as among others WhatsApp (WA), Instagram, Telegram or Vlog (Video blog).

\section{CONCLUTION}

On the basis of the descriptions above, it can be concluded that the Engineering of the civic virtue- and local wisdom character education model in the Civic 
Education is conducted through a series of research and development so that it may produce a learning model different from the previous ones. It is because the preparation of the model has considered empirical and accountable data, therefore it may result in a better and more practical, more effective and efficient, more pleasing/interesting, more usable and more acceptable course. The research would be better if it is conducted by an institution with adequate authority and capability.AP3KnI (Association of Pancasila and Civic Educators) for example may serve as one of the supporting and implementing partner institutions to implement the Civic Education course which is in line with the learning outcomes expected by the government and the society.

\section{REFERENCES}

[1] Gall, M.D., J.P.Gall \& W.R. Borg, Educational Research: AnIntroduction. Boston: Pearson Education.. 2007.

[2] Gustafson, K.L., \& Branch, R. M.,(2002). Survey of Instructional Development Models (4•h ed.). Syracuse University, Syracuse, NY: ERIC Clearing houseon Information \&Technology.

[3] Sukmadinata, N.S. Curriculum and Competency Learning. Bandung: Kesuma Karya.2010.
Tim PPK, PASKA - Sekjen Kemendikbud. Concepts and Guidelines for Strengthening Character Education, Second Print, Jakarta: Kemendikbud RI. 2017.

[4] Wulandari, Taat. 2016. Social Engineering Collaborative Education Character and Multicultural Education: Praxis at Yayasan Perguruan Sultan Iskandar Muda, Journal of Education Development: Foundation and Application, Volume 4, Number 2, December 2016.

[5] Winarni,S., (2013).Integration of Character Education in Lectures. Journal of Character Education, FIK Yogyakarta State University, YearIII, Number1, February 2013.

[6] Zuriah, Nurul, Sunaryo, Hari. (2017).Social Engineering Character Education Model Based on Civic Virtue and Local Wisdom in High Colleges as an Effort to Strengthen Human Resources and Nation Competitiveness, National Strategic Research Report Phase II of 2017, Ditbinlitabmas Dikti. 